\title{
Pengaruh Ketahanan Terhadap Kebahagiaan Perkawinan Pada Pasangan Perjodohan Usia Dini
}

\section{The Effect of Resilience on Marital Happiness in Couples of Early Marriage}

\author{
Netty Herawati ${ }^{*}$, Nurul Kameliya ${ }^{1}$, Binti Mafrukhatul Unaifah ${ }^{1}$ \\ ${ }^{1}$ Fakultas Ilmu Sosisl dan Ilmu Budaya, Universitas Trunojoyo Madura \\ *herawati.netty9@gmail.com
}

\begin{abstract}
Abstrak
Penelitian ini bertujuan untuk mengetahui pengaruh ketahanan terhadap kebahagiaan perkawinan pada pasangan perjodohan usia dini. Metode penelitian menggunakan pendekatan kuantitatif dengan teknik purposive sampling. Responden dalam penelitian ini adalah pasangan perjodohan usia dini dengan jumlah 60 responden. Instrumen dalam penelitian ini adalah skala resiliensi dan skala kebahagiaan perkawinan. Analisis data menggunakan uji regresi linier sederhana. Hasil penelitian ini menunjukkan signifikansi sebesar $0,00(0,00<0,05)$. Artinya hipotesis diterima yaitu terdapat pengaruh ketahanan terhadap kebahagiaan perkawinan pada pasangan perjodohan. Nilai koefisien pengaruh $(\mathrm{r})$ sebesar 0,654, dengan demikian terdapat pengaruh ketahanan terjhadap kebahagiaan perkawinan pada pasangan perjodohan usia dini. Adapun sumbangan efektif ketahanan terhadap kebahagiaan perkawinan sebesar $42,7 \%$, sisanya $57,3 \%$ dipengaruhi oleh faktor lain.
\end{abstract}

Kata Kunci : Ketahanan, Kebahagiaan Perkawinan, Pasangan Perjodohan usia dini

\begin{abstract}
The purpose of this study was to find out the effect of resilience on marital happiness in early marriage couples. The methods of this research was quantitative approach and purposive sampling techniques. The subject of this research were 60 respondents early marriage couples. Resilience scale and marital happiness scale were used respectively to measure the resilience and marital happiness. The result of parametric statistical analysis using linier regression showed that there was a positive effect and significant $0,00<0,05)$. This means that hypothesis was accepted. The effect of resilience on marital happiness in couples of early marriage with coefficient was 0,654 . The effective contribution of resilience on marital happiness in couples of early marriage was $42,7 \%$ and $57,3 \%$ was effected by other factors.
\end{abstract}

Kata Kunci : Resiliensi, marital happiness, couples in early marriage

\section{Pendahuluan}

Sebagai makhluk sosial, manusia memiliki kebutuhan untuk membangun hubungan dengan orang lain. Hubungan yang dekat dengan orang lain dapat ditandai dengan saling mencintai, peduli, komitmen, dan keintiman. Salah satu langkah untuk mengikat hubungan tersebut adalah melalui suatu ikatan suci dalam sebuah pernikahan. Pernikahan didefinisikan sebagai suatu ikatan antara laki-laki dan perempuan yang telah menginjak usia dewasa ataupun dianggap telah dewasa dalam ikatan yang sakral (Marlina, 2013). Dalam hubungan pernikahan ini, setiap individu mengharapkan kebahagiaan dalam perkawinannya. Dalam mencapai kebahagiaan tersebut, individu melakukan berbagai upaya untuk mewujudkannya. 
Namun demikian, tidak semua perkawinan didasari oleh adanya perasaan cinta, ada juga karena hasil perjodohan. Di Indonesia sendiri masih sering kita jumpai perkawinan dari hasil perjodohan tak terkecuali di Madura (Herawati, 2019). Pola perkawinan pada masyarakat Madura masih identik dengan pola perkawinan endogami. Perkawinan endogami menurut Fatoni (2016) adalah kecenderungan menikah dengan kerabat sendiri. Tujuan perkawinan endogami adalah untuk mempertahankan ikatan keluarga. Model perjodohan semacam ini, dalam bahasa Madura dikenal dengan istilah mapolong tolang artinya menyambungkan tali kekeluargaan. Menurut Insumar, dkk (2017) perjodohan adalah upaya untuk melakukan atau menyatukan kedua anak manusia pada salah satu pihak dengan adanya pemaksaan. Sayangnya banyak perjodohan yang dilakukan pada usia dini.

Menurut Herawati (2019) perjodohan orang madura merupakan suatu bentuk ketaatan, ketundukan, dan berupa kepatuhan terhadap figur orang tua, sebagaimana yang terdapat dalam peribahasa Maduara Bhu,pa', bhabbu', guru ban rato yaitu kepatuhan kepada empat figur utama ayah, ibu, guru dan pemimpin pemerintah. Perjodohan adalah salah satu bentuk kepatuhan kepada salah satu figur tersebut diatas. Perjodohan yang dilakukan di Madura tidak hanya sejak mereka masih kanakkanak bahkan sejak di dalam kandungan, antar orang tua sudah sepakat menjodohkan Ketika putra putri yang akan mereka lahirkan kelak berbeda jenis kelamin. Walaupun perjodohan semacam ini hanya terjadi di salah satu Kabupaten di Madura, namun hingga kini keberadaannya masih tetap ada sekalipun sudah masa milenial atau bahkan generasi Z.

Batas usia dalam melaksanakan perkawinan menjadi hal yang harus diperhatikan. Hal ini karena di dalam perkawinan sendiri menghendaki adanya kematangan psikologis. Pada dasarnya menikah sendiri adalah tugas perkembangan bagi mereka yang memiliki usia dewasa awal. Teori psikologi perkembangan menyatakan bahwa menikah merupakan tugas dari dewasa awal. Pada dewasa awal jika dibandingkan dengan masa remaja secara fisik mereka sudah matang dalam mengambil keputusan dan memecahkan masalah para dewasa ini sudah mampu berpikir abstrak, logis, dan rasional (Aprianti, 2015).

Sedangkan mereka yang menikah di usia remaja belum memiliki kematangan secara psikologis sehingga akan berpengaruh pada kehidupan perkawinannya. Seperti yang dinyatakan oleh Pujiwati (2014) bahwa kondisi psikologis pada usia remaja cenderung labil sehingga mempengaruhi kehidupan pernikahan, dimana akan sering terjadi konflik dalam rumah tangga, karena kurang dapat mengendalikan diri dan berpkiran dewasa. Pernikahan di usia remaja ini disebut dengan pernikahan dini, yaitu sebelum mereka berusia 19 tahun, sebagaimana Undang-Undang Perkawinan nomor 16 tahun 2019 bahwa Batasan usia menikah minimal 19 tahun.

Pernikahan dini sendiri mempunyai potensi yang lebih besar berakhir pada perceraian. Seperti yang dikemukakan oleh Supriyanti (2013) bahwa dampak dari pernikahan di bawah umur adalah sering terjadinya perceraian. Pada umumnya pernikahan dini yang dilakukan secara resmi akan berakhir dengan perceraian. Hal ini seperti yang diungkapkan oleh Suciati (2019) yang mengemukakan bahwa angka perceraian di Indonesia terbilang cukup tinggi dan kasus perceraian yang paling banyak adalah dari pernikahan dini..

Meskipun beberapa daerah di wilayah Madura melakukan pernikahan perjodohan di usia dini, namun tidak sedikit dari mereka masih mampu mempertahankan perkawinannya hingga saat ini. Sari (2015) mengemukakan bahwa mayoritas masyarakat Madura yang melakukan pernikahan di usia muda jarang terjadi perceraian dan mereka bisa mendapat keharmonisan dalam pernikahannya. Yusfitasari (2018) juga menyatakan dalam penelitiannya bahwa pernikahan dini yang terjadi di wilayah Jambi sudah biasa dilakukan karena mereka yakin bahwa dengan menikah di usia dini dapat mendewasakan diri dan bijaksana dalam bertindak sehingga disaat memiliki pasangan dapat merasakan kehidupan yang penuh dengan kebahagiaan.

Sebelumnya Hairi (2009) juga mengemukakan bahwa pernikahan dini baik untuk pertumbuhan emosi dan mental, sehingga lebih memungkinkan dapat mencapai puncak kematangan. Pernikahan akan mematangkan seseorang sekaligus untuk memenuhi separuh dari kebutuhan-kebutuhan psikologis, yang pada gilirannya akan menjadikan individu mampu mencapai puncak pertumbuhan kepribadian yang mengesankan.

Agustin (2013) juga mengungkapkan hal yang sama bahwa tujuan dari pernikahan adalah untuk membentuk keluarga yang bahagia selamanya. Begitupun juga pada pasangan yang menikah muda. Pujiwati (2014) menyatakan bahwa bagi sebagian orang yang memutuskan untuk menikah di usia muda sebagai pilihannya akan lebih mudah merasakan kebahagiaan. Pernikahan yang dijalaninya 
akan memberikan kesenangan. Selain itu sebagian orang yang merasakan kebahagiaan saat menikah muda karena merasa mendapat pengalaman atau tantangan untuk dijalaninya bersama dengan pasangan yang dicintainya.

Kebahagiaan perkawinan sendiri oleh Herawati (2015) didefinisikan sebagai kesejahteraan kehidupan perkawinan secara keseluruhan yang meliputi kesenangan lahiriah dan batiniah. Kebahagiaan perkawinan memiliki beberapa aspek yaitu: (1) kepuasan perkawinan; (2) afeksi positif negatif; (3) penerimaan jati diri; (4) relasi positif dengan pasangan; (5) otonomi: (6) penguasaan lingkungan; (7) pengembangan diri; (8) tujuan hidup perkawinan.

Diener, dkk (2005) mengatakan bahwa orang yang berbahagia adalah individu yang menikah, mempertahankan pernikahannya serta merasakan kebahagiaan dalam pernikahannya. Jadi individu dikatakan bahagia apabila individu tersebut sudah menikah dan mampu mempertahankan pernikahannya dari segala macam hal yang berpotensi membuat pernikahan tersebut berakhir. Begitu juga individu yang menikah karena perjodohan di usia dini akan merasakan kebahagiaan dalam pernikahannya jika mereka mampu mempertahankan pernikahannya. Seperti yang dikatakan oleh Julianto (2016) bahwa permasalahan perceraian dan keluarga tergantung pada bagaimana kekuatan yang ada pada setiap keluarga. Mereka yang dapat bertahan dalam menghadapi konflik pernikahan mempunyai kekuatan yang kuat dalam bertahan menghadapi permasalahan yang ada.

Menurut Desmita (2015) kemampuan bertahan merupakan kemampuan yang dibutuhkan dalam kehidupan setiap orang. Apalagi bagi pasangan perjodohan usia dini yang cenderung memiliki kondisi psikologis masih cenderung labil sehingga untuk menghadapi konflik yang terjadi cenderung meragukan kemampuan yang dimilikinya untuk mengatasi permasalahan. Mereka juga belum banyak memiliki pengetahuan yang cukup untuk menyelesaikan permasalahan yang ada. Ketahanan diperlukan untuk mengajarkan bagaimana cara mereka bertahan menghadapi permasalahan dalam pernikahannya. Seperti yang dikemukakan oleh Maulidya \& Eliana (2013) bahwa ketahanan penting untuk memperluas dan menambah pengalaman individu dalam menyelesaikan suatu permasalahan.

Ketahanan atau disebut juga Resiliensi menurut Connor dan Davidson (2003) adalah kualitas personal yang memungkinkannya untuk berkembang dalam menghadapi kesulitan dalam hidupnya dimana dengan kualitas tersebut diharapkan individu dapat bangkit dari kesulitan. Resiliensi memiliki beberapa aspek yaitu: (1) kompetensi pribadi, standar yang tinggi dan ketahanan; (2) kepercayaan seseorang pada naluri, toleransi terhadap pengaruh negatif, memiliki kekuatan untuk menghadapi pengaruh stress; (3) penerimaan diri yang positif terhadap perubahan dan hubungan aman dengan orang lain; (4) kemampuan untuk mengontrol diri; (5) pengaruh spiritual. Pasangan yang memiliki kemampuan untuk bisa bertahan dan menyelesaikan konflik mempunyai kesempatan untuk mendapatkan pernikahan yang bahagia.

Olson \& DeFrain (2006) menyatakan bahwa bahagia atau tidak bahagianya suatu hubungan dapat dilihat dari bagaimana pasangan dapat mengelola konflik yang terjadi. Menurut Reivich dan Shatte (2002) resiliensi diperlukan setiap individu untuk menghadapi permasalahan, tekanan, serta konflik yang terjadi. Individu yang resilien akan menggunakan sumber dari dalam dirinya sendiri. Sumber tersebut digunakan untuk mengatasi setiap masalah yang ada, tanpa harus terbebani dan bersikap negatif terhadap kejadian tersebut.

Individu yang resilien adalah individu yang tidak memunculkan simtom-simtom patologis pada situasi-situasi yang cenderung negatif atau mengancam. Saat sakit dan stress dalam menghadapi problem hidup individu individu tersebut dapat kembali menemukan cara untuk keluar dari masalah yang dihadapi serta kembali bangkit sehingga dapat menjadi lebih baik dari sebelumya. Bagi individu yang memiliki kemampuan resiliensi akan membuat seseorang berhasil menyesuaikan diri saat berhadapan dengan kondisi-kondisi yang tidak menyenangkan (Sofia, 2017).

Sebagaimana yang dikemukakan oleh UU No 1 Tahun 1947 bahwa tujuan dari pernikahan adalah kebahagiaan. Seligman (2005) mengungkapkan bahwa orang yang berbahagia bukanlah orang yang tidak pernah mengalami penderitaan. Kebahagian tidak bergantung pada seberapa banyak peristiwa menyenangkan yang dialami melainkan sejauh mana seseorang memiliki resiliensi.

Individu dengan resilien yang baik adalah mereka yang berhasil mengatasi permasalahan mereka, bahkan mampu bangkit menjadi individu yang lebih kuat, lebih baik dan menemukan kehidupan yang lebih baik dari sebelumnya. Pribadi dengan resilien yang tinggi akan mampu keluar dari masalah dengan cepat dan tidak terperangkap dalam perasaan sebagai korban dari lingkungan atau keadaan dan mampu mengambil keputusan (Siebert, 2005). Sejalan dengan hal ini pasangan 
pernikahan dini yang notabennya memiliki banyak permasalahan baik dalam hal kematangan psikis, ketidakstabilan emosi dan kurangmya kemampuan dalam menghadapi permasalahan akan dapat bertahan dan mencapai kebahagiaan perkawianan jika pasangan pernikahan dini memiliki kemampuan resilien. Hal ini sesuai dengan penelitian yang dilakukan oleh Sakdiyah \& Fatma (2015) yang mengungkapkan bahwa resiliensi merupakan aspek pembentuk utama dari kebahagiaan pernikahan pada pasangan yang menikah dengan persiapan dan tanpa persiapan. Pernyataan ini diperkuat oleh penelitian yang dilakukan oleh Min-Kyeong dan Kyung-Ae (2012) yang menyatakan bahwa ketahanan keluarga berkorelasi positif dengan kebahagiaan perkawinan. Kebahagiaan perkawinan tetap dapat tercapai pada keluarga multikultural yang mengalami konflik-konflik dengan adanya ketahanan keluarga.

Kehidupan pernikahan, apalagi pada pernikahan perjodohan dan di usia dini selalu menghadapi tantangan dan permasalahan atau konflik. Namun, manakala individu mampu beradaptasi terhadap konflik atau permasalahan dalam pernikahannya, ia akan memiliki kemampuan untuk bangkit, berusaha berkembang menjadi individu yang lebih kuat, lebih bijak dan lebih menghargai kehidupan maka individu tersebut akan merasakan kebahagiaan dalam pernikahannya.

Herawati (2015) mendefinisikan kebahagiaan perkawinan merupakan kesejahteraan kehidupan perkawinan secara keseluruhan yang meliputi kesenangan lahiriah dan batiniah. Aspek-aspek dari kebahagiaan perkawinan adalah menurut Herawati (2015) yaitu:

a. Kepuasan Perkawinan

Kepuasan perkawinan merupakan suatu perasaan subjektif yang dirasakan oleh pasangan suami istri dalam perkawinannya karena telah mencapai kebahagiaan secara lahir maupun batin dengan terpenuhinya kebutuhan, harapan dan tujuan yang diinginkan dalam perkawinannya.

b. Afeksi Positif dan Negatif

Afeksi positif dan negatif adalah bagaimana pasangan suami istri dapat memahami pasangannya satu sama lainnya. Mereka mengerti apa yang diinginkan dan tidak diinginkan oleh pasangannya.

c. Penerimaan Jati Diri (Self Acceptance)

Dimensi ini mencakup kemampuan pasangan untuk menerima berbagai macam kondisi diri mulai dari yang positif sampai negatif. Selain itu juga menggambarkan sejauhmana pasangan dapat menerima pengalaman masa lalu sebagai bagian dari diri sendiri yang tidak perlu ditolak dan dapat bersikap positif terhadap diri sendiri dan pernikahannya.

d. Kemampuan Menjalin Hubungan Positif dengan Pasangan

Kebahagiaan perkawinan diukur melalui sejauhmana pasangan dapat memperlihatkan perhatiannya kepada pasangannya, mampu berempati, membangun kepercayaan dalam hubungan yang akrab, mencintai dan berbagai kasih sayang dengan pasangannya.

e. Kebebasan Bertindak (Otonomi)

Otonomi berarti mempunyai kemampuan untuk mengarahkan diri sendiri, menentukan keputusan secara mandiri, menilai sesuatu berdasarkan standard pribadi dalam arti tidak selalu bergantung kepada hal-hal eksternal

f. Kemampuan untuk Menguasai Lingkungan secara Efektif (Environmental Mastery)

Termasuk dalam dimensi ini yaitu kemampuan untuk merubah lingkungan agar sesuai dengan keterbatasan fisik, menggunakan setiap kesempatan secara efektif dan mampu memilih serta memilah kondisi yang sesuai dengan minat maupun nilai-nilai yang dimiliki.

g. Pengembangan Diri (Personal Growth)

Termasuk dalam dimensi ini yaitu kemampuan untuk mengembangkan potensi diri secara berkesinambungan, bersikap terbuka terhadap berbagai pengalaman dan informasi baru, menerima kenyataan dan menghargai prestasi.

h. Keyakinan bahwa Hidupnya Bermakna dan Mempunyai Tujuan (Purpose in Life)

Orang yang bahagia dengan perkawinannya merasa bahwa hidupnya memiliki makna dan tujuan hidupnya terarah pada hal yang diyakini sebagai sesuatu yang baik.

Sedangkan resiliensi menurut Connor dan Davidson (2003) merupakan kualitas personal yang memungkinkannya untuk berkembang dalam menghadapi kesulitan dalam hidupnya dimana dengan kualitas tersebut diharapkan individu dapat bangkit dari kesulitan. Connor dan Davidson (2003) menjelaskan bahwa ada beberapa aspek untuk mengukur resiliensi seseorang yaitu:

a. Kompetensi pribadi, standar yang tinggi, dan ketahanan 
Aspek ini menyokong kekuatan seseorang untuk kuat dan setia pada satu tujuan ketika dihadapkan pada situasi yang traumatic, kemunduran (tidak takut menghadapi kegagalan). Individu yang mempunyai tujuan hidup akan akan memperjuangkan kesehatan mentalnya ketika dihdapkan denagan situasi dan lingkungan yang tidak menyenangkan.

b. Seseorang dapat percaya pada nalurinaya sendiri, mentoleransi dampak negatif, dan kuat dalam menghadapi stress.

Aspek ini berhubungan dengan ketenangan dan ketepatan individu sehingga dapat mengambil keputusan yang terbaik dan juga tepat saat mengatasi tekanan yang sulit. Individu tetap mampu melihat sisi positif dari suatu kejadian yang penuh tekanan.

c. Seeorang dapat menerima perubahan dengan positif dan memiliki hubungan yang aman

Individu dapat menerima dengan positif terhadap perubahan-perubahan yang terjadi pada dirinya dan sekitarnya serta dapat menjalin hubungan yang positif dengan orang lain dan lingkungannya. Hal tersebut menggambarkan kemampuan individu untuk dapat beradaptasi jika menghadapi perubahan dalam situasi yang buruk atau ketika terjadi bencana.

d. Kemampuan untuk mengontrol diri

Aspek ini menggambarkan kemampuan mengendalikan diri serta kegigihan dalam mencapai tujuan sehingga ketika dihadapkan pada kesulitan individu tidak akan mudah putus asa dan cepat bangkit kemabli kembali dari keadaan tersebut. Selain itu, kemampuan mengontrol tersebut akan membantu individu untuk meningkatkan keterampilannya dalam pemecahan masalah sosial.

e. Pengaruh spiritual

Aspek ini memperlihatkan keyakinan individu atas takdir yang Tuhan berikan. Hal ini dikarenakan peran iman dan keyakinan dianggap sebagai proses intervensi yang akan membantu individu untuk mencari jalan keluar dari permaslahan dan dapat memberikan dampak yang positif dalam kelangsungan hidup individu itu sendiri.

\section{Metode Penelitian}

Penelitian ini menggunakan pendekatan kuantitatif. Bentuk skala yang digunakan dalam penelitian ini adalah skala ordinal dari Likert. Instrumen yang digunakan dalam penelitian ini terdiri dari dua skala yaitu skala kebahagiaan perkawinan dan skala resiliensi. Keduanya disusun berdasarkan aspek dari masing-masing variabel. Skala kebahagiaan perkawinan terdiri dari 45 item pertanyaan dan skala resiliensi terdiri dari 27 item pernyataan dengan lima alternatif jawaban.

Populasi pada penelitian ini adalah pasangan perjodohan usia dini. Sampel yang digunakan sejumlah 60 orang. Penelitian ini menggunakan teknik purposive sampling, yaitu teknik penentuan sampel berdasarkan kriteria tertentu (Sugiyono, 2015). Pada penelitian ini karakteristik sampelnya adalah sebagai berikut:

a. Pasangan Perjodohan

b. Pasangan pernikahan dini

Berdasarkan Undang-Undang perkawinan nomor 16 tahun 2019 dikategorikan pernikahan dini jika pasangan berusia sebelum 19 tahun

b. Masa perkawinan di bawah 10 tahun

Menurut Anjani dan Suyanto (2006) konflik dalam rumah tangga terjadi pada rentang usia perkawinan antara 1-10 tahun.

c. Wilayah Madura

PIK-KRR menyatakan perkawinan di usia dini meningkat di Pulau Madura. Menurut Kepala BKKBN Jawa Timur (2015) bahwa pernikahan dini merata di empat kabupaten yaitu Bangkalan, Sampang, Pamekasan dan Sumenep.

Adapun teknik analisis data menggunakan uji regresi linier sederhana dengan bantuan software SPSS 23.0

\section{Hasil Penelitian}

Berdasarkan hasil uji regresi sederhana yang telah dilakukan menunjukkan bahwa nilai $\mathrm{F}$ hitung sebesar 51,441 dengan signifikansi sebesar 0,00 $(<0,05)$ yang berarti hipotesis diterima. Nilai koefisien pegaruh sebesar 0,654 dengan nilai signifikansi sebesar $0,00 \quad(<0,05)$. Artinya terdapat pengaruh ketahanan terhadap kebahagiaan perkawinan pada pasangan perjodohan usia dini. 
Tabel 1 Uji Regresi Sederhana ANOVA

\begin{tabular}{ccccccc}
\hline & Model & Sum of Squares & df & Mean Square & F & Sig. \\
\hline 1 & Regression & 17231.909 & 1 & 17231.909 & 51.441 & $.000^{\mathrm{b}}$ \\
& Residual & 23114.063 & 59 & 391.764 & & \\
& Total & 40345.972 & 60 & & & \\
\hline
\end{tabular}

a. Dependent Variable: Kebahagiaan Perkawinan

b. Predictors: (Constant), Ketahanan

Tabel 2 Model Summary Nilai Koefisien Pengaruh

\begin{tabular}{cccccccc}
\hline & & & \multicolumn{3}{c}{} & & \multicolumn{3}{c}{ Change Statistics } \\
\cline { 7 - 8 } Model & $\mathbf{R}$ & R Square & Square & $\begin{array}{c}\text { Std. Error of } \\
\text { the Estimate }\end{array}$ & $\begin{array}{c}\text { R Square } \\
\text { Change }\end{array}$ & $\begin{array}{c}\text { F } \\
\text { Change }\end{array}$ & df1 \\
\hline 1 & $.654^{\mathrm{a}}$ & .427 & .419 & 18.303 & .427 & 51.441 & 1 \\
\hline
\end{tabular}

a. Predictors: (Constant), Ketahanan

b. Dependent Variable: Kebahagiaan Perkawinan

\section{Pembahasan}

Hasil penelitian menunjukkan bahwa terdapat pengaruh ketahanan terhadap kebahagiaan perkawinan pada pasangan perjodohan usia dini. Arah pengaruh menunjukkan koefisien positif Hal ini menunjukkan bahwa semakin tinggi tingkat ketahanan maka kebahagiaan perkawinan juga semakin meningkat. Sesuai dengan pernyataan Seligman (2005) bahwa orang yang berbahagia bukan berarti orang yang tidak pernah mengalami penderitaan. Kebahagiaan tidak tergantung pada seberapa banyak peristiwa menyenangkan yang dialami. Melainkan sejauh mana seseorang memiliki resiliensi.

Sebagaimana yang dinyatakan oleh Diener (2005) dalam penelitiannya menyebutkan bahwa orang yang berbahagia adalah individu yang menikah, mempertahankan pernikahannya serta merasakan kebahagiaan dalam pernikahannya. Herawati (2015) menyatakan bahwa kebahagiaan perkawinan merupakan kesejahteraan kehidupan perkawinan secara keseluruhan yang meliputi kesenangan lahiriah dan batiniah. Namun, untuk mencapai kebahagiaan perkawinan bukanlah hal yang mudah karena kebahagiaan perkawinan dipengaruhi oleh banyak faktor (Sakdiyah dan Fatma, 2015).

Dalam realitanya, tidak dapat dipungkiri bahwa dalam menjalankan kehidupan perkawinan, konflik akan selalu muncul dalam setiap kehidupan berumah tangga (Aprianti, 2015). Apalagi jika pasangan tersebut menikah karena perjodohan dan terjadinya pernikahan di usia dini. Disamping penyesuaian perkawinan sendiri membutuhkan energi dan waktu, usia yang masih belum stabil menjadikan pasangan lebih ekstra dalam menjalani kehidupan perkawinannya. Davidson dan Moore (1996) menyatakan bahwa hal-hal yang menyebabkan konflik rumah tangga adalah tugas rumah tangga, pekerjaan, kurang perhatian dan kasih sayang dari pasangan, serta ketidakhadiran anak.

Adapun dalam menghadapi konflik-konflik dalam pernikahan tersebut, ada pasangan yang dapat mempertahankan pernikahannya dan ada yang memilih untuk berpisah. Data yang diperoleh dari Muhyidin dan Yulianto (2018) kasus perceraian rata-rata naik 3 persen per tahunnya. Seperti yang dikatakan oleh Julianto dan Saidiyah (2016) bahwa permasalahan perceraian dan keluarga tergantung pada bagaimana kekuatan yang ada pada setiap keluarga. Mereka yang dapat bertahan dalam menghadapi konflik pernikahan mempunyai kemampuan yang kuat dalam bertahan menghadapi permasalahan yang ada.

Sebagaimana pernyataan dari Olson dan DeFrain (2006) bahwa bahagia atau tidak bahagianya suatu hubungan dapat dilihat dari bagaimana pasangan dapat mengelola konflik a tau permasalahan yang terjadi. Herawati (2015) menyebutkan bahwa pasangan yang mempunyai kemampuan dalam mengambil keputusan, menghadapi dan menyelesaikan setiap persoalan-persoalan yang ada dalam pernikahannya tentu akan lebih bahagia dari pada mereka yang tidak mampu mengambil keputusan dan menyelesaikan persoalan dalam pernikahannya. Hal ini menunjukkan bahwa pasangan yang menikah dapat mencapai kebahagiaan dalam pernikahannya jika salah satunya mereka dapat bertahan dan menyelesaikan permasalahan-permasalahan yang terjadi dalam pernikahannya. Seperti yang diungkapkan oleh Maulidya dan Eliana (2013) yang menyatakan bahwa kemampuan resiliensi penting untuk memperluas dan menambah pengalaman individu dalam menyelesaikan suatu permasalahan. 
Kemampuan bertahan atau resiliensi merupakan kemampuan yang dibutuhkan dalam kehidupan setiap orang (Desmita, 2015). Apalagi pada pasangan perjodohan yang melakukan pernikahan dini. Menurut Supriyanti (2013) dampak dari perkawinan di bawah umur adalah sering terjadi perceraian. Hal ini karena kondisi psikis dan fisik mereka yang masih belum matang sehingga belum stabil dalam kehidupan keluarga, kebutuhan ekonominya kurang karena mereka tidak mempunyai pengetahuan yang cukup sehingga apabila muncul permasalahan dalam keluarga seperti permasalahan ekonomi, kebahagiaan dalam keluarga, mereka tidak mampu mengatasinya dimana dapat menimbulkan masalah yang sulit untuk diselesaikan dan mempengaruhi penyesuaian dalam perkawinannya. Menurut Jannah, dkk (2016) menyebutkan bahwa perkawinan yang masih belum cukup usia atau dibawah umur memberikan dampak yang berpotensi menjadi sebuah trauma. Kemunculan trauma ini diakibatkan oleh ketidaksiapan menjalanakan tugas-tugas perkembangan yang muncul setelah adanya perkawinan. Pujiwati (2014) juga menyebutkan bahwa usia yang belum matang membuat kondisi psikologis pasangan yang menikah di bawah umur masih labil, sehingga ini akan mempengaruhi kehidupan pernikahan mereka sehingga akan sering terjadi konflik dalam rumah tangga karena kurang dapat mengendalikan diri dan pemikrian dewasa.

Suyasa (2011) menyatakan bahwa dengan kepribadian yang resilien akan menjadi alternatif sumber kebahagiaan yang ada dalam diri seseorang. Hal ini karena orang dengan kepribadian yang resilien memiliki karakter untuk selalu kembali atau selalu mempertahankan kondisi/ perasaan baik yang dimilikinya, walaupun individu mengalami berbagai gejolak/permasalahan dalam hidupnya. Menurut Dewi, dkk (2014) individu yang resilien akan berusaha untuk mengatasi permasalahan dalam hidup, sehingga dapat terbebas dari masalah dan mampu beradapatasi terhadap permasalahan tersebut. Individu yang mempunyai kepribadian yang resilien akan mampu mengalami perasaan senang/puas, tidak menyesali atau tidak mengeluh terhadap hal-hal yang terjadi, merasakan bahwa hidup ini bermakna, memiliki tujuan dan penuh dengan harapan. Dengan adanya kemampuan resiliensi tersebut, pasangan pernikahan dini akan mampu bertahan dan mengatasi kesulitan yang mereka hadapi dalam pernikahannya meskipun dengan kondisi kematangan emosi yang masih belum matang atau labil. Resiliensi yang mereka miliki akan mampu membuat mereka mempertahankan pernikahannya dan mencapai kebahagian perkawinan seperti tujuan pernikahan yang pada dasarnya adalah untuk mecapai suatu kebahagiaan.

Hasil dari penelitian ini mendukung penelitian yang telah dilakukan oleh Chudori (2000) yang menyebutkan bahwa kebahagiaan yang sejati dalam sebuah perkawinan bukan hanya karena keindahan, kenikmatan dan kemesraan belaka, namun yang utama adalah jika keduanya mampu mengatasi persoalan yang timbul di dalam rumah tangga. Penelitian lain yang sejalan dengan penelitian ini adalah penelitian yang dilakukan oleh Sakdiyah dan Fatma (2015) yang menyebutkan bahwa resiliensi merupakan aspek pembentuk utama dari kebahagiaan pernikahan baik dengan persiapan maupun tanpa persiapan. Resiliensi memberikan kontribusi yang lebih besar dari aspekaspek lainnaya. Individu yang mampu beradaptasi dengan permasalahan yang ada dalam perkawinannya, memiliki kemampuan untuk bangkit, berusaha berkembang menjadi individu yang lebih kuat, lebih bijak dan lebih menghargai kehidupan, maka individu tersebut akan merasakan kebahagiaan dalam perkawinan

Hasil dari penelitian ini juga sejalan dengan penelitian yang dilakukan oleh Min-Kyeong dan Kyung-Ae (2012) yang juga menyatakan bahwa ketahanan keluarga memiliki korelasi positif dengan kebahagiaan perkawinan. Kebahagiaan perkawinan tetap dapat tercapai pada kelurga multikultural yang mengalami konflik-konflik dengan adanya ketahannan keluarga. Ketahanan keluarga memberikan efek yang positif yang berkontribusi pada kebahagiaan perkawinan.

Dapat disimpulkan bahwa mereka yang menikah karena perjodohan membutuhkan penyesuaian yang lebih baik dan pernikahan di usia dini memiliki konflik yang lebih kompleks. Hal ini karena individu yang menikah di usia dini belum memiliki emosi yang stabil sehingga dalam menyelesaikan masalah lebih mengedepankan emosi dari pada pikiran sehat sehingga mereka kurang mampu melihat masalah secara objektif dan lebih sering memunculkan perselisihan (Marlina, 2013).

Melihat hal tersebut resiliensi sangat diperlukan dalam keberlangsungan pernikahan dini karena masalah yang mereka alami lebih kompleks daripada mereka yang menikah di usia yang matang. Resiliensi bisa membuat mereka bertahan dalam menghadapi permasalahan untuk mencapai tujuan pernikahan yaitu kebahagiaan. 
kontribusi atau sumbangan efektif esiliensi terhadap kebahagiaan perkawinan pada penelitian ini sebesar 42,7\%, Sedangkan 57,3\% lainnya dipengaruhi oleh faktor lain yang tidak diteliti dalam penelitian ini. Faktor-faktor lain yang tidak diteliti dalam penelitian ini adalah latar belakang kepribadian suami atau istri yang meliputi keadaan ekonomi, sosial, budaya; latar belakang keluarga suami atau istri yang meliputi kebiasan, nilai dan norma.

\section{Kesimpulan}

Hasil penelitian ini menunjukkan bahwa terdapat pengaruh resiliensi terhadap kebahagiaan perkawinan pada pasangan perjodohan usia dini. Hasil uji regresi linier sederhana yang telah dilakukan menunjukkan bahwa F hitung sebesar 51,441 dengan signifikansi sebesar 0,00 $(<0,05)$, sehingga hipotesis diterima, yaitu terdapat pengaruh antara resiliensi dengan kebahagiaan perkawinan pada pasangan perjodohan usia dini.

Nilai koefisien pengaruh (r) sebesar 0,654 dapat diidentifikasikan bahwa terdapat pengaruh dengan kategori kuat. Nilai koefisien determinasi (R Square) sebesar 0.427, Dengan demikian resiliensi memiliki pengaruh terhadap kebahagiaan perkawinan sebesar 42,7\%, sedangkan 57,3\% lainnya dipengaruhi oleh faktor lain yang tidak diteliti.

\section{Daftar Pustaka}

Agustin, H. (2013). Gambaran Kehidupan Psangan yang Menikah di Usia Muda di Kabupaten Dharmasraya. Spektrym PLS. 1(1).

Aprianti, Kareti. (2015). Gambaran Gara Resolusi Konflik pada Pasangan yang Menikah Dini di Kabupaten Bandung.

Azwar, Saifuddin. (2017). Metode Penelitian Psikologi Edisi II. Yogyakarta: Pustaka Pelajar.

Basti, Dewi Eva. (2008). Konflik Perkawinan dan Model Penyelesaian Konflik pada Pasangan Suami Istri. Jurnal Psikologi. 2 (1).

Connor, K.M \& Davidson, J.R.T. (2003). Development of a New Resilience Scale: The Connor-Davidson Resilience Scale (CD-RISC). Depression and Anxiety, 18.

Chudori, Human Santoso. (2000). Liku-liku Perkawinan. Jakarta: Pustaka Pembangunan Swadaya Nusantara (PUSPA SWARA).

Davidson, J.K dan Moore, N.B. (1996). Marriage and Family: Change and Continuity. Boston: Allyn and Bacon.

Desmita. (2015). Psikologi Perkembangan. Bandung: PT. Remaja Rosdakarya.

Dewi, Eva M.P, Basti. 2008. Konflik Perkawinan dan Model Penyelesaian Konflik pada Pasangan Suami Istri. Jurnal Psikologi. 2 (1).

Diener, E,dkk. (2005). Subjective Well Being: The Science of Happiness and Life Satisfaction. Handbook of Positive Psychology. Oxford: Oxford University Press.

Hairi. (2009). Fenomena Pernikahan di Usia Muda di Kalangan Masyarakat Muslim Madura (Studi Kasus di Desa Bajur Kecamatan Waru Kabupaten Pamekasan. Yogyakarta: Fakultas Ushuluddin. Universitas Islam Negeri Sunan Kalijaga.

Herawati, Netty (2015). Model Kebahagiaan Perkawinan Pasangan Etnis Madura Berdasarkan Peran Nilai Budaya Perkawinan, Religiusitas Islam dan Komitmen Perkawinan. Bandung: Universitas Padjajaran.

(2019). Culture Matchmaking in Madurese Ethnic : A Study of The Motives, Factors and Impacts in Marriage Life. International Journal of Psychosocial Rehabilitation. ISSN: 1475-7192

Insumar, P, K. dkk. (2017). Perjodohan Sebagai Penyebab Terjadinya Perceraian. Vol. 6, No. 2.

Jannah, Miftahul, dkk. (2016). Dampak Psikologis pada Perkawinan Remaja di Jawa Timur. Jurnal Penelitian Psikologi. 7 (2).

Julianto, Very dan Saidiyah, Saith. (2016). Problem Pernikahan dan Startegi Penyelesaiannya: Studi Kasus pada Pasangan Suami Istri dengan Usia Perkawinan Dibawah Sepuluh Tahun. Jurnal Psikologi Undip. 15 (2).

Kyung Ae, Park dan Kyeong, Kim Min. (2012). Relationship Between Daily Life Conflicts, Depression, Family Resilience, and Marital Happiness of Intermarried Korean Men. Asosiasi Manajemen Sumber Daya Keluarga Korea Selatan. 16 (1). 
Marlina, N. (2013). Hubungan antara Tingkat Pendidikan Orang Tua dan Kematangan Emosi dengan Kecenderungan Menikah Dini. Empathy. 2 (1).

Maulidya, Mutia dan Eliana, Rika. (2013). Gambaran Resiliensi Perantau Minangkabau yang Berwirausaha di Medan. Psikologia. 8 (1)

Olson, H. David dan Defrain, John. (2006). Marriages and Families: Intimacy, Diversity, and Strenghts, $5^{\text {th }}$ ed. USA: McGraw Hill.

Periantalo, Jelpa. (2016). Penelitian Kuantitatif untuk Psikologi. Yogyakarta: Pustaka Pelajar.

Pujiwati, Rahayu Fitri. (2014). Kebahagiaan dan Ketidakbahagiaan pada Wanita Menikah Muda. Surakarta: Fakultas Psikologi. Universitas Muhammadiyah Surakarta.

Reivich, K \& Shatte, A. (2002). The Resilience Factor; 7 Essential Skill For Overcoming Life's Inevitable Obstacle. New York: Broadway Books.

Romauli, S dan Vindari, A. (2010). Kesehatan Reproduksi buat Mahasiswa Kebidanan. Yogyakarta: Nuha Medika.

Sakdiyah, Elok Halimatus dan Fatma, Sofia Halida. (2015). Perbedaan Kebahagiaan Pasangan Pernikahan dengan Persiapan dan Tanpa Persiapan pada Komunitas Young Mommy Tuban. Jurnal Psikologi Tabularasa. 10 (1).

Santrcok, John W. (2012). Perkembangan Masa Hidup, Edisi Ketigabelas, Jilid II. Jakarta: PT. Gelora Aksara Pratama

Sari, Titi Nur Indah. (2016). Fenomena Pernikahan Usia Muda di Masyarakat Madura. Jakarta: Fakultas Syariah dan Hukum. Universitas Islam Negeri Syarif Hidayatullah.

Seligman, Martin E.P. (2005). Authentic Happiness: Using the New Positive Psychology to Realize YourPotential for Lasting Fulfillment. New York: Free Press.

Siebret, A. (2005). The Resilience Advantage: Master Change, Thrive Under Pressure, and Bounce Back From Set Backs. San Fransisco: Berrette-Koehler.

Sofia, Danies Nur Kholifatus. (2017). Dinamika Resiliensi pada Janda Cerai Muda (Studi Kasus pada Wanita Dewasa Awal sebagai Orang Tua Tunggal di Desa Panggunguni Kecamatan Pucanglaban Kabupaten Tulungagung). Tulungagung: Fakultas Ushuluddin Adab dan Dakwah. Institut Agama Islam Negeri (IAIN) Tulungagung.

Supriyanti, Nika. (2003). Pengaruh Pernikahan Dini terhadap Perilaku Pasangan Suami Istri pada Desa Pepe, Kecamatan Tegowanu. Semarang: Fakultas Ilmu Pengetahuan Sosial. IKIP PGRI Semarang.

Suyasa., P.Tommy Y.Sumatera (2011). Kepribadian Resilien sebagai Lokasi Kebahagiaan. Jakarta: Universitas Tarumanagara. 